\title{
Growth and survival of juvenile Pomacea canaliculata (Gastropoda: Ampullariidae) in plain streams associated to different land uses
}

\author{
Ana Clara Ferreira ${ }^{a, b, c}$ and Alberto Rodrigues Capítulo o,b,c \\ aLaboratorio de Bentos, Instituto de Limnología "Raúl A. Ringuelet" (ILPLA), La Plata, Argentina; 'bacultad de Ciencias Naturales y Museo \\ (UNLP), La Plata, Argentina; 'Consejo Nacional de Investigaciones Científicas y Técnicas (CONICET), Ciudad Autónoma de Buenos Aires, Argentina
}

\begin{abstract}
Pomacea canaliculata is an apple snail that has become an invasive species in several countries. In this research, through two simultaneous experiments, we assessed the effects of different land uses (urban, agriculture, cattle grazing, farms and recreation) on the growth and survival of snails from native populations. The survival was not affected by the water quality of the three streams studied, whereas the growth of snails exposed to the water of the urban stream was impaired. Therefore, our results suggest that the growth rate of $P$. canaliculata could be useful for the assessment of a moderate urban impact.
\end{abstract}

ARTICLE HISTORY

Received 7 April 2016

Accepted 8 February 2017

\section{KEYWORDS}

Water quality;

bioassessment; land use;

snails; lowland streams

\section{Introduction}

The ecological integrity of aquatic ecosystems around the world is being threatened by the modifications of human land uses in their catchments (Allan 2004) and the pampasic lowland streams of Argentina are no exception. The expansion of soybean crops and the fast growth of urban settlements in this region have led to an important change in land uses (Paruelo et al. 2005; Viglizzo et al. 2006), with severe consequences on lotic ecosystems such as habitat destruction, nutrient enrichment and pollution of water and sediments (Quirós et al. 2006; Cortelezzi et al. 2013; Amuchástegui et al. 2015).

The channeled apple snail, Pomacea canaliculata (Lamarck 1822), is very abundant in the lotic systems of the Pampasic lowlands (Seuffert \& Martin 2013a). This species is native to the La Plata River basin and was introduced in the 1980s to several countries of Asia, later expanding its distribution to Oceania, Europe (delta of Ebro River), the USA (Hawaii and many continental states) and other South American countries where it was not present before, such as Ecuador and Chile (Rawlings et al. 2007; Hayes et al. 2008; Jackson \& Jackson 2009; López Soriano et al. 2009; Horgan et al. 2014). Currently, apple snails cause both severe economic and ecological problems, and therefore have been listed among the 100 worst alien species (Joshi 2007; Fang et al. 2010). In views of the need for knowledge about the management of this species, the number of publications dealing with its biological, physiological and ecological features rose in the past three decades (for a review see Hayes et al. 2015). Field studies on native populations, in contrast, are limited to the presence or absence of the species in certain water bodies under natural conditions (Martin et al. 2001; Martin \& Estebenet 2002; Tietze \& de Francesco 2010; Seuffert \& Martín 2013a), and the potential impact of human activities on their biological traits remains poorly studied.

The invasiveness of $P$. canaliculata is favored by the high survival and fast growth rate of juvenile snails (Cowie 2002; Morrison \& Hay 2011; Chaichana \& Sumpan 2015). Such traits, however, can be affected by several factors, with the water temperature, the amount and quality of the food available, and the density of snails among the most influential variables (Cazzaniga \& Estebenet 1988; Tanaka et al. 1999; Morrison \& Hay 2011; Qiu et al. 2011; Seuffert \& Martín 2013b). It is also known that some chemical substances, such as heavy metals, fertilizers and tributyltin (TBT) can also affect the growth and survival of these snails (Giraud-Billoud et al. 2013; Stuart et al. 2014). Peña and Pocsidio (2007), for example, found that high concentrations of copper can cause a significant retardation in growth of mature $P$. canaliculata snails and similar results were described for the Florida apple snail, Pomacea paludosa (Hoang et al. 2008). Additionally, Coler et al. (2005) reported that even after a short exposure, the herbicides Paraquat and 
Round-up ${ }^{\circledR}$ can also cause a decrease in the growth of the sensitive newly hatched Pomacea lineata snails. In our research the growth and survival of juvenile $P$. canaliculata snails were assessed after exposure to the water of three streams from basins with different land uses. Although not all the biotic and abiotic factors were known and controlled, we aimed to find functional responses provided by the snails (such as a lower growth rate and survival) that could be useful for future water quality analysis. Since human impact on urban streams is frequently high (Walsh et al. 2005), we expected to find a lower survivorship and growth of snails exposed to the water of a urban stream (Martín), followed by the snails exposed to water from a rural area (Zapata) in which agriculture, cattle grazing, farms and food industries are the main human activities. The highest survival and growth rate was expected for snails reared in the water of a low impacted stream (El Pescado).

\section{Materials and methods}

\section{Site selection}

The Pampean streams (streams located in the Pampean plains of Buenos Aires Province, Argentina) are low order water bodies (2-4) characterized by the lack of riparian forests and by low current, elevated alkalinity and hardness, and high concentrations of oxygen and nutrients of $\mathrm{N}$ and $\mathrm{P}$ in water, favoring a natural eutrophic state (Feijoó et al. 2005; Feijoó \& Lombardo 2007). The different land uses, however, can determine differences in the water chemistry at a basin scale (Amuchástegui et al. 2015). The three basins chosen for this study (Martín, Zapata and El Pescado streams) are located at the northeast of Buenos Aires province, where typical argiudols determine soils suitable for cultivation (INTA 1990). Besides the crops, cattle grazing, industries and urban settlements constitute the main land uses of the region (Gómez \& Licursi 2001; Amuchástegui et al. 2015). These basins were chosen after the analysis of land cover maps (Hurtado et al. 2006; INTA 2016) and the information from previous regional studies carried out in the Institute of Limnology Raul Ringuelet (ILPLA) (Figure 1). The basin of Martín stream is about $25 \mathrm{~km}^{2}$. At its upper portion, there is an intense agricultural activity dominated by greenhouse production of vegetables and flowers. The mid portion of the basin, where the sampling point was set $\left(34^{\circ} 52^{\prime} 28^{\prime \prime}\right.$, $58^{\circ} 04^{\prime} 13^{\prime \prime} \mathrm{W}$ ), runs through a semi-urban zone near La Plata city (the second largest urban conglomerate of the province after Buenos Aires city). Here, the stream receives untreated domestic wastewater and the effluents of a pharmaceutical factory located $700 \mathrm{~m}$ upstream. The ecological integrity of this stream is threatened by accumulation of garbage and regular dredging (Cortelezzi et al. 2013). Previous studies have reported nutrients enrichment at this site, whereas the heavy metal, herbicide and pesticide concentrations in water and sediments lay below the risky values stated by the USEPA and the Canadian Council of Ministries of Environment, CCME, 2014 (Sierra 2008; Cortelezzi 2010; Cortelezzi et al. 2013; Ferreira 2015). The basin of the Zapata stream is about $135 \mathrm{~km}^{2}$ and it is located in a rural area. At the

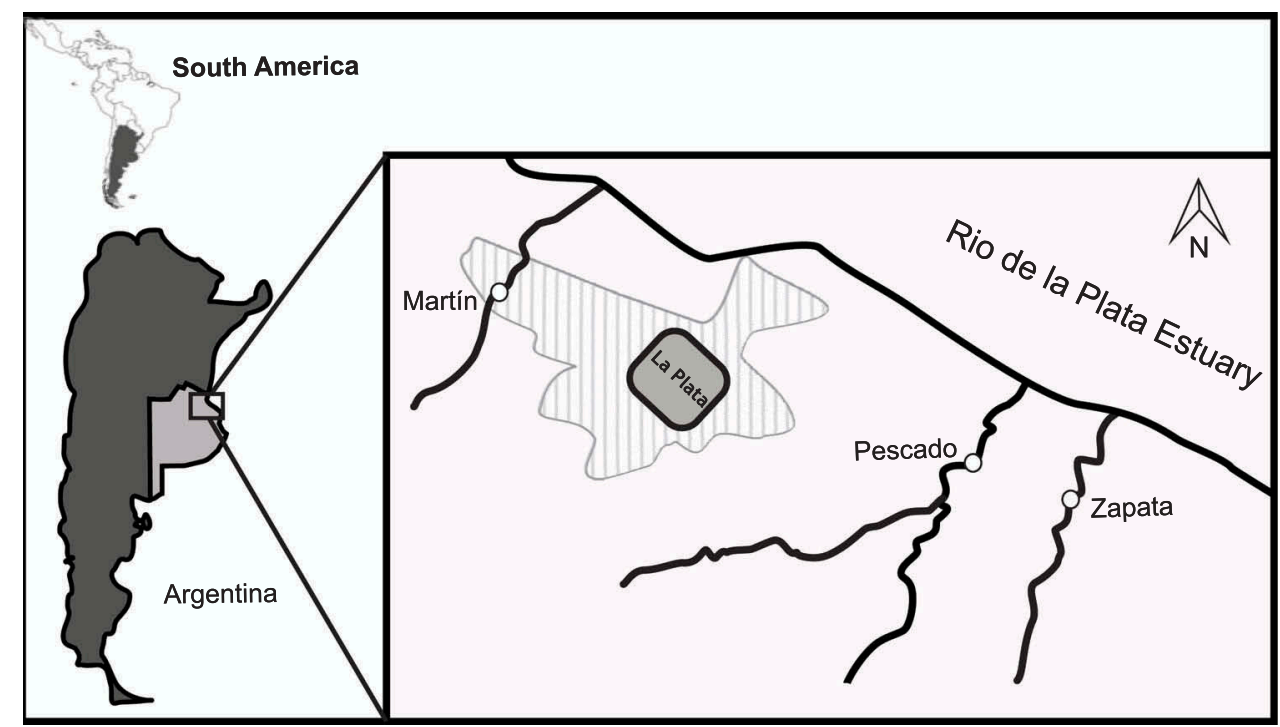

Figure 1. Study area. White spots indicate the sampling point at each stream. The most urbanized areas in the study area are indicated (La Plata city and surroundings). 
upper portion, the main land uses are agriculture, intensive cattle grazing and chicken farms, along with a small urban settlement and a food industry. The selected sampling point is located at the mid basin ( $\left.34^{\circ} 59^{\prime} 19^{\prime \prime} \mathrm{S}, 57^{\circ} 42^{\prime} 59^{\prime \prime} \mathrm{W}\right)$ and, although the extensive cattle grazing is the main land use at this zone, Paracampo (2012) reported a strong impact of the upstream land uses on the water quality of the stream, which was reflected on an impoverished fish community and the presence of tolerant species. With about $311 \mathrm{~km}^{2}$, El Pescado basin is the biggest of this zone. The site sampled is also located at the mid basin $\left(34^{\circ}\right.$ $57^{\prime} 37^{\prime \prime} \mathrm{S}, 57^{\circ} 46^{\prime} 40^{\prime \prime} \mathrm{W}$ ), where the main land uses are extensive cattle grazing and recreation. Although this site is placed downstream from an intense crop area, the presence of a natural wetland favors the improvement of the water quality downstream, reflected, for example, in the presence of sensitive species such as the shrimp Macrobrachium borellii (Rodrigues Capítulo et al. 2001; Mugni 2008). This site has been considered as a reference site for previous studies (see Graça et al. 2002).

\section{Experimental setup}

To assess the impact of different land uses on growth and survival of $P$. canaliculata, two simultaneous experiments were conducted in which we exposed juvenile snails to water from the three selected streams (treatments). Mineral water was used as a control to test whether the differences between treatments were due to the water quality of the streams or because of intrinsic variations of the populations (Estebenet \& Martín 2002). We chose a commercial mineral water after registering that the young snails had a lower mortality than in tap and moderately hard water. The stream water for the experiments was collected every one or two weeks (eight times in total) along with additional water samples used for the analysis of oxygen demands (BOD: biochemical oxygen demand; COD: chemical oxygen demand) and nutrient concentrations (nitrites, nitrates, ammonium and soluble reactive phosphorous (SRP) under standardized methods (APHA 1998). At the laboratory, the stream water was filtered with sieves (mesh size $250 \mu \mathrm{m}$ ) to exclude floating plants and small animals such as microcrustaceans, and $\mathrm{pH}$ and conductivity of stream and mineral water were measured with a multiparameter HORIBA U10 sensor. Since the experiments were constantly aerated and under controlled room temperature, the dissolved oxygen and water temperature were not measured.
The experiments were done with newly hatched snails (0-3 days old) because of their low mortality rate and their potential sensitivity to water pollution (Estebenet \& Cazzaniga 1992; Coler et al. 2005). The snails were obtained from several egg masses collected at the three streams. To guarantee genetic variability, one pool per population was made with the snails hatched within a period of $72 \mathrm{~h}$ prior to the experiments. In both experiments, snails were exposed, under controlled conditions (room temperature $24 \pm 3^{\circ} \mathrm{C}$; 12:12 artificial photoperiod), to their corresponding stream water (treatments Ms, Ps and Zs, for snails from Martín, El Pescado and Zapata streams, respectively) and to commercial mineral water (controls $\mathrm{Mc}$, $\mathrm{Pc}$ and $\mathrm{Zc}$ for snails from Martín, El Pescado and Zapata streams, respectively). Snails were fed ad libitum every one or two days with lettuce (Lactuca sativa L.) after Estebenet (1995), discarding the old lettuce to avoid water quality impoverishment. Experiments were conducted under the animal care committee of the Institute of Limnology R. A. Ringuelet.

\section{Survival experiment}

For the survival experiment, an initial number of 100 young snails were placed in each 91 aquarium (three treatments and three controls per stream, resulting in a total of 18 trials). The survival in each aquarium was checked once a week during the first three weeks and every two weeks afterwards. Snails were considered dead if: (a) the shell was empty; (b) the body tissues were white, emerging from the shell and not responding to external stimuli; or (c) if no movement was observed after $5 \mathrm{~min}$ of observation (Melo et al. 2000). Dead individuals were removed to avoid water deterioration and not replaced. In addition to weekly partial water changes, water was completely replaced immediately after checking survival. The total exposure time was 11 weeks. At the end of the experiment the shell length of surviving individuals was measured with a digital caliper (resolution $0.01 \mathrm{~mm}$ ).

\section{Growth experiment}

Before the exposure to stream and mineral water, 10 newly hatched $P$. canaliculata snails from each stream were measured to determine the initial size. For each stream, 200 newly hatched snails were placed in groups of five individuals in 40 pots of $250 \mathrm{ml}$ capacity. Twenty pots were filled with the corresponding stream water and 20 with mineral water. As the snails grew up, the density of individuals was set as follows to avoid the effects of crowding: 1 snail/50 $\mathrm{ml}$ for first three weeks, 1 snail/ 
$100 \mathrm{ml}$ at the fourth week, 1 snail/ $125 \mathrm{ml}$ at the fifth week and 1 snail $/ 300 \mathrm{ml}$ at the sixth week. The snails were measured weekly during the first five weeks, and every two weeks afterwards until the end of the experiment at the end of the seventh week. Since the youngest individuals were too small to be handled and measured with caliper, 10 snails from each treatment and control were randomly chosen every time, sacrificed and fixed in alcohol $70 \%(\mathrm{v} / \mathrm{v})$ for their measurement under stereoscopic microscope $(10 \times)$ with micrometric ocular. Measurements included the aperture height (AH) (Estebenet 1998), which was transformed to total length (TL) of the shell for posterior comparisons with the literature through the formula $\mathrm{TL}=0.697+1.273^{\star} \mathrm{AH}$ $\left(\mathrm{R}^{2}: 0.99 ; p<0.01 ; N: 533\right)$.

\section{Statistical analyses}

One-way analysis of variance (ANOVA) was used to check for differences in physicochemical variables among streams $(N=8$ for each variable). Normality and homogeneity were previously tested using Kolmogorov-Smirnov test and Cochran's test respectively. The Dunn's method was used to compare the water of the streams against the control.

The values of survival recorded each time were compared through a two-way ANOVA the main factors "Stream" (with three levels: Martín, El Pescado and Zapata) and "water" (with two levels: stream and mineral water), whereas the final size achieved by snails at the end of the experiment was compared with a one-way ANOVA. The a posteriori Student-Neuman-Keuls (SNK) test was performed after both analyses.

The differences in size of snails from the three streams at the beginning of the experiment were compared through a one-way ANOVA ( $\alpha$ 0.05), whereas to assess the differences after the seven weeks of exposure, a two-way ANOVA was performed, with the main factors "Stream" (with three levels: Martín, El Pescado and Zapata) and "water" (with two levels: stream and mineral). In both cases, Student-Neuman-Keuls (SNK) was used as the a posteriori test. In addition, differences in growth rates (slopes comparisons) were assessed by analysis of covariance (ANCOVA; confidence interval: 95\%, tolerance: 0.0001 ), followed by a Tukey a posteriori test. For this analysis, the values of shell length (dependent variable) were linearized using logarithmic transformation; time (weeks) was set as independent variable.

\section{Results}

\section{Water quality}

The water of all streams was slightly alkaline ( $\mathrm{pH}$ between 7.3 and 8.5) and had low values of $\mathrm{BOD}_{5}$ and COD (Table 1). The highest means of conductivity and SRP were recorded in the water of the urban stream, Martín, whereas the site with highest agricultural impact, Zapata, had the highest mean levels of $\mathrm{NO}_{3}-$ and $\mathrm{NH}_{4}+$ (Table 1). However, the observed differences among streams were not statistically significant. The values of all parameters in the water from Martín stream except $\mathrm{pH}$ showed statistically significant differences with the control mineral water, whereas the water from El Pescado and Zapata streams differed from the control only in the values of $\mathrm{NO}_{2}-$ and oxygen demands.

\section{Survival}

The survival of snails from the streams Martin (Ms and $\mathrm{Mc}$ ) and El Pescado (Ps and Pc) was over 90\% during the entire experiment, whereas this parameter decreased for snails from Zapata stream achieving a final value almost three times lower than those recorded for the other populations (about 34\%; Table 2). Such differences were evident since the second week of exposure until the end of the experiment (Figure 2). The final size of shell length also showed statistical differences among the

Table 1. Mean values $( \pm \mathrm{SD})$ of the physicochemical variables recorded in the commercial mineral water (control, $N=8)$ and the stream water $(N=8)$.

\begin{tabular}{|c|c|c|c|c|}
\hline Parameters & Control & Martín & El Pescado & Zapata \\
\hline $\mathrm{pH}$ & $7.7 \pm 0.5$ & $7.9 \pm 0.3$ & $8.0 \pm 0.4$ & $7.7 \pm 0.3$ \\
\hline Conductivity $\left(\mu \mathrm{S} \mathrm{cm}^{-1}\right)$ & $223 \pm 42$ & $918 \pm 570 *$ & $766 \pm 372$ & $632 \pm 343$ \\
\hline $\operatorname{SRP}\left(m g P i^{-1}\right)$ & $0.02 \pm 0.00$ & $0.52 \pm 0.53 *$ & $0.18 \pm 0.21$ & $0.17 \pm 0.09$ \\
\hline $\mathrm{NO}_{3}-\left(\mathrm{mg} \mathrm{N} \mathrm{I}^{-1}\right)$ & $0.57 \pm 0.08$ & $0.07 \pm 0.07 *$ & $0.31 \pm 0.41$ & $0.58 \pm 1.27$ \\
\hline $\mathrm{NO}_{2}-\left(\mathrm{mg} \mathrm{N}^{-1}\right)$ & $<0.001$ & $0.02 \pm 0.02 *$ & $0.03 \pm 0.03^{*}$ & $0.02 \pm 0.02 *$ \\
\hline $\mathrm{NH}_{4}+\left(\mathrm{mg} \mathrm{N} \mathrm{I}^{-1}\right)$ & $0.06 \pm 0.01$ & $0.11 \pm 0.05 *$ & $0.06 \pm 0.05$ & $0.13 \pm 0.13$ \\
\hline $\mathrm{BOD}_{5}\left(\mathrm{mg} \mathrm{O}_{2} \mathrm{I}^{-1}\right)$ & 0 & $8 \pm 5 *$ & $8 \pm 4^{*}$ & $12 \pm 4^{*}$ \\
\hline $\operatorname{COD}\left(\mathrm{mg} \mathrm{O}_{2} \mathrm{I}^{-1}\right)$ & 0 & $22 \pm 2 *$ & $20 \pm 9 *$ & $21 \pm 4$ * \\
\hline
\end{tabular}

${ }^{*} p<0.05$. Comparison between stream water and the control.

Abbreviations: SRP, soluble reactive phosphorous; $\mathrm{NO}_{3}-$, nitrates; $\mathrm{NO}_{2}-$, nitrites; $\mathrm{NH}_{4}+$, ammonia; $\mathrm{BOD}_{5}$, biochemical oxygen demand; $\mathrm{COD}$, chemical oxygen demand. 
Table 2. Results of the two-way ANOVA and Student-Neuman-Keuls (SNK) a posteriori test for the final survival values.

\begin{tabular}{lcccccl}
\hline Source & Levels & df & SS & $F$ & $p$ & \\
\hline Stream & $3(\mathrm{M}, \mathrm{P}, \mathrm{Z})$ & 2 & 12820.8 & 298.15 & $<0.01$ & $\mathrm{M}=\mathrm{P}>\mathrm{Z}$ \\
Water & $2(\mathrm{~m}, \mathrm{~s})$ & 1 & 24.5 & 1.14 & 0.31 & $\mathrm{NS}$ \\
Stream $x$ water & & 2 & 4.33 & 0.1 & 0.905 & NS \\
& & & & & Stream (m): $\mathrm{M}=\mathrm{P}>\mathrm{Z}$ \\
& & & & & Stream (s): $\mathrm{M}=\mathrm{P}>\mathrm{Z}$ \\
& & & & & Water (stream): $\mathrm{M}, \mathrm{P}$ and Z: $s=\mathrm{m}$ \\
\hline
\end{tabular}

Abbreviations: M, Martín; P, El Pescado; Z, Zapata; m, mineral water; s, stream water; NS, not significantly different.

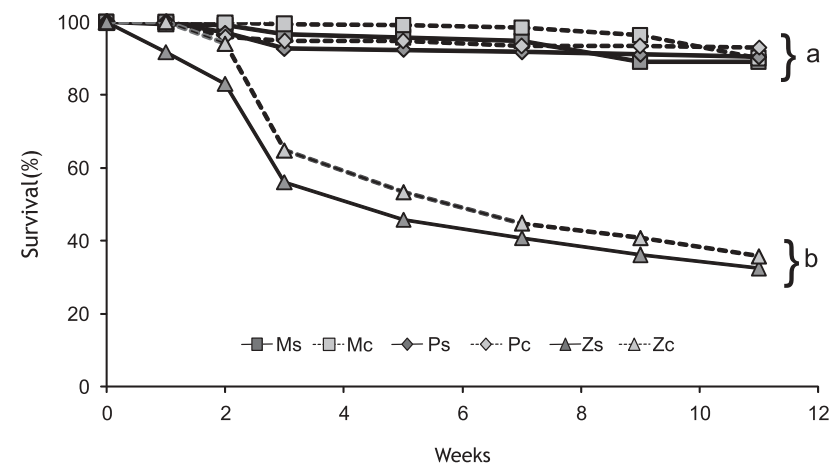

Figure 2. Survival curves for Pomacea canaliculata snails from Martín (M), El Pescado (P) and Zapata (Z) streams. Ms, Ps and Zs: snails exposed to stream water; Mc, Pc and Zc: snails exposed to commercial mineral water (controls). Different letters indicate significant differences at the end of the experiment (Student-Neuman-Keuls test). The brackets group the treatments that lack of statistical differences.

three populations $(p<0.001)$, with snails from Zapata stream (Zs and $\mathrm{Zc}$ ) being the longest and those from Ms the shortest (Figure 3).

\section{Growth of snails}

Mean shell length of newly hatched snails from Zapata $(3.37 \pm 0.17 \mathrm{~mm})$ was statistically larger $(p<0.05)$ than

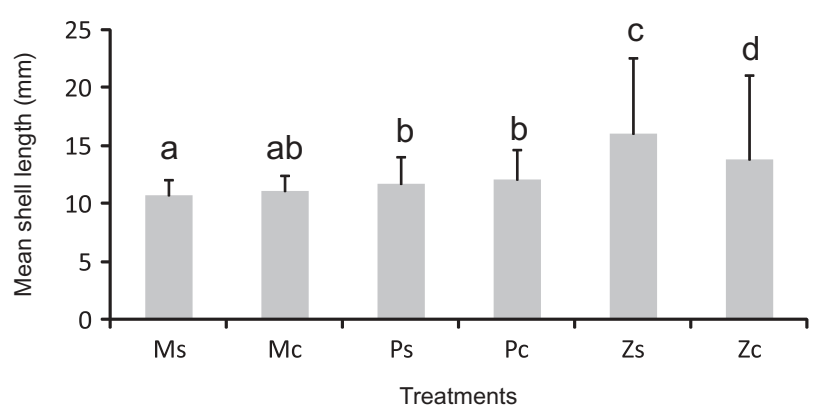

Figure 3. Comparison of mean shell length ( \pm SD) of the surviving Pomacea canaliculata snails between treatments (Ms, Ps and Zs: snails from Martín, El Pescado and Zapata populations exposed to stream water; Mc, Pc and Zc: snails from those populations exposed to commercial mineral water). Different letters indicate significant differences in size at the end of the experiment (Student-Neuman-Keuls test). those of snails from El Pescado and Martín streams $(3.19 \pm 0.19 \mathrm{~mm}$ and $3.12 \pm 0.15 \mathrm{~mm}$, respectively). After seven weeks, however, no significant differences in the shell length of snails were found among the three trials, except for snails from Ms, which were smaller $(p<0.05$; Figure 4). Accordingly, the slope of the growth curves for Ms was significantly lower than in the other trials $(p<0.001$; ANCOVA).

\section{Discussion}

\section{Water quality}

The concentration of nutrients showed the same trend reported in previous regional studies: higher concentrations of SRP in the urban stream (Martín) and higher concentrations of $\mathrm{NO}_{3}-$ and $\mathrm{NH}_{4}+$ in the site with higher impact from agriculture (Zapata) (Sierra 2008; Cortelezzi 2010; Paracampo 2012). Despite the fact that the physicochemical parameters measured in the water during this study did not exhibit significant differences, probably due to the high variation they presented during the study period at each site, snails reared in the urban stream had a significantly lower growth. Urban streams are subjected to biological, physical and chemical degradation, known as the "urban stream syndrome" (Walsh et al. 2005; Booth et al. 2016). Besides nutrients, chemical pollution can be

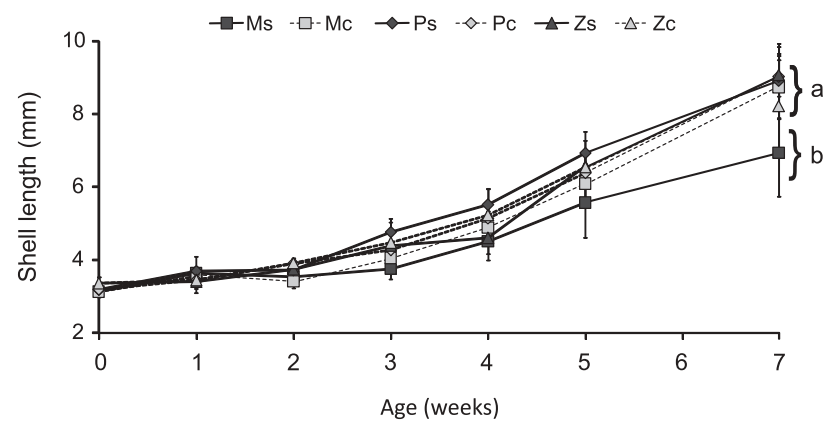

Figure 4. Growth curves for Pomacea canaliculata snails from Martín, El Pescado and Zapata streams. Ms, Ps and Zs: snails exposed to stream water; Mc, Pc and Zc: snails exposed to commercial mineral water (controls). Different letters indicate significant differences in growth at the end of the experiment (Student-Neuman-Keuls test). The brackets group the treatments that lack of statistical differences. 
associated to causes such as pharmaceutical and personal care products (PPCPs), a group of emergent pollutants associated with urban land uses which study has risen in the last decades. These kind of substances reach the water bodies mainly through wastewaters and can produce acute or chronic effects (mainly on growth and reproduction) on different vertebrate and invertebrates species (see Boxall et al. 2012; Brausch et al. 2012; for a review). Although there are no studies that analyze the presence of PPCPs compounds in the waters of Martín stream, recent research did report high concentrations of these substances in nearby streams in the same urban area (Elorriaga et al. 2013). Since the Martín stream receives not only untreated wastewaters, but also the discharges of a pharmaceutical industry, the effects of PPCPs on the biota need to be considered in further studies.

\section{Survival}

The survival of snails from El Pescado and Martín streams is in accordance with the survival expected for snails reared under laboratory conditions (Estebenet \& Cazzaniga 1992; Estebenet \& Martín 2002; Seuffert \& Martín 2013b). Such values of survival (>90\%) were higher than expected for the snails exposed to the water from the urban stream, suggesting that the level of pollution of Martín stream is not high enough to produce an acute effect on young $P$. canaliculata snails, or that the newly hatched are not as sensitive as presumed. Although previous studies showed that adult specimens of $P$. canaliculata are tolerant to a wide range of environmental conditions (Estebenet \& Martín 2002; Chaichana \& Sumpan 2015), ongoing experiments in streams with higher human impact might contribute to the knowledge of the sensitivity of young snails before discarding them as indicators of water quality.

The survival of snails from Zapata stream, on the other hand, was much lower than of those reared in water from Martín and El Pescado streams. After studying different traits of close populations of $P$. canaliculata, Martín and Estebenet (2002) suggested that the interpopulation variation can be due to features that are influenced by the environmental conditions (ecophenotypic variation) or by genetic differences among populations. In our study, if survival had been influenced by the environmental conditions, no differences would have been observed among the controls of the three populations. Moreover, the survival of $\mathrm{Zc}$ was not significantly different from $\mathrm{Zs}$, suggesting that this population would be genetically different from the populations from Martín and El Pescado streams. In addition, the initial size of newly hatched snails as well as the final size of the few surviving snails from Zapata stream were bigger than in snails from the other populations, suggesting that this population shows a higher intraspecific competition in which a few stronger individuals grow and survive in detriment of the weakest.

Therefore, at moderate levels of pollution, the survival of $P$. canaliculata is not informative and the results might be influenced by genetic variation. Under these conditions, we conclude that survival should not be used as an alternative tool for the assessment of the impact of human activities.

\section{Growth of snails}

The results of the growth experiment, on the other hand, suggest that there was an environmental effect on the growth of snails from Martín stream reared in stream water (Ms). Low $\mathrm{pH}$ and calcium concentration (hardness) are among the water parameters that can influence growth of apple snails (Glass \& Darby 2009), but the water of Martín stream is alkaline and hard $\left(126 \mathrm{mg} \mathrm{CaCO}_{3}\right.$; Cortelezzi 2010), which may be why these two variables do not explain the slower growth of snails reared in stream water. High copper concentrations in water and sediments can also cause a lower growth of Pomacea species (Peña \& Pocsidio 2007; Hoang et al. 2008; Hoang \& Rand 2009), but previous studies reported copper concentrations in sediments of Martín stream lower than toxic levels $(<15$ $\mu \mathrm{g} \mathrm{g}^{-1}$ of soil; Sierra 2008; Cortelezzi 2010; Ferreira 2015). Pounds et al. (2008) reported an impaired growth of the snail Planorbis carenatus (Planorbidae) exposed to high concentrations of ibuprofen, one of the most abundant drugs recorded in the nearby urban streams (Elorriaga et al. 2013). Therefore, further studies should analyze the presence of this substance in Martín stream and its impact on the growth of $P$. canaliculata should be assessed through laboratory cause-effect experiments.

\section{Perspectives}

The experiments conducted in this study were useful for the identification of interpopulation differences probably based on genetic variability. In addition, sensitivity of growth rate to water affected by urban environments suggests that the study of this feature could be a useful indicator of urban pollution, but further field and laboratory studies, especially cause-effect studies, would help understanding which of the multiple possible factors present in the urban streams affect the growth of this species.

\section{Acknowledgments}

We would like to express our thanks to J. Donadelli (ILPLA) for the chemical analysis of water samples and Dr E. Speranza for the field and laboratory assistance. This paper 
is the Scientific Contribution No.978 of the Dr R.A. Ringuelet Institute of Limnology (ILPLA, CCT-La Plata, CONICET, UNLP).

\section{Disclosure statement}

No potential conflict of interest was reported by the authors.

\section{Funding}

This work was supported by the National Agency for the Promotion of Science and Technology of Argentina (ANPCyT) [grant PICT N ${ }^{\circ}$ 33939]; the Argentinean National Council of Scientific and Technical Research (CONICET) [grant PIP number 0341]; and the Faculty of Natural Science and Museum (FCNyM) [grant number 0635].

\section{References}

[INTA] Instituto Nacional de Tecnología Agropecuaria. 1990. Atlas de suelo de la República Argentina. SagypINTA-Proyecto PNUD ARG. 1(Avellaneda):731 p.

[INTA] Instituto Nacional de Tecnología Agropecuaria. 2016. Cobertura y usos de suelo de Argentina. [cited 2016 Feb 5]. Available from: http://geointa.inta.gov.ar/visor.

Allan JD. 2004. Landscapes and riverscapes: the influence of land use on stream ecosystems. Annu Rev Ecol Evol S. 35:257-284.

Amuchástegui G, di Franco L, Feijoó C. 2015. Catchment morphometric characteristics, land use and water chemistry in Pampean streams: a regional approach. Hydrobiologia. 767:65-79.

APHA. 1998. Standard methods for the examination of water and wastewater. Washington (DC): American Public Health Association.

Booth DB, Roy AH, Smith B, Capps KA. 2016. Global perspectives on the urban stream syndrome. Freshw Sci. 35:412-420.

Boxall ABA, Rudd MA, Brooks BW, Caldwell DJ, Choi K, Hickmann S, Innes E, et al. 2012. Review pharmaceuticals and personal care products in the environment: what are the big questions? Environ Health Persp. 120:1221-1229.

Brausch JM, Connors KA, Brooks BW, Rand GM. 2012. Human pharmaceuticals in the aquatic environment: a review of recent toxicological studies and considerations for toxicity testing. Rev Environ Contam Toxicol. 218:1-99.

Cazzaniga NJ, Estebenet AL. 1988. The effect of crowding on breeding Pomacea canaliculata (Gastropoda: ampullariidae). Comp Physio Ecol. 13:89-96.

Chaichana R, Sumpan T. 2015. Environmental tolerance of invasive golden apple snails (Pomacea canaliculata (Lamarck, 1822)) and Thai native apple snails (Pila scutata (Mousson, 1848)). Trop Ecol. 56:347-355.

Coler R, Coler RR, Felizardo EKG, Watanabe T. 2005. Applying weight gain in Pomacea lineata (Spix 1824) (Mollusca: prosobranchia) as a measure of herbicide toxicity. Braz J Biol. 65:617-623.

Cortelezzi A. 2010. Hábitats funcionales y macroinvertebrados en cauces modificados de arroyos de llanura: impacto sobre la calidad ecológica [PhD Thesis]. [La Plata]: National University of La Plata (UNLP).
Cortelezzi A, Sierra MV, Gómez N, Marinelli C, Rodrigues Capítulo A. 2013. Macrophytes, epipelic biofilm, and invertebrates as biotic indicators of physical habitat degradation of lowland streams (Argentina). Environ Monit Assess. 185:5801-5815.

Cowie RH. 2002. Apple snails (Ampullariidae) as agricultural pests: their biology, impacts and management. In: Barker GM, editor. Molluscs as crop pests. Wallingford: CABI. p. 145-192.

Elorriaga Y, Marino DJ, Carriquiriborde P, Ronco AE. 2013. Screening of pharmaceuticals in surface water bodies of the Pampas region of Argentina. Int J Environ Heal. 6:330-339.

Estebenet AL. 1995. Food and feeding in Pomacea canaliculata (Gastropoda: ampullariidae). The Veliger. 38:277-283.

Estebenet AL. 1998. Allometric growth and insight on sexual dimorphism in Pomacea canaliculata (Gastropoda: ampullariidae). Malacologia. 39:207-213.

Estebenet AL, Cazzaniga NJ. 1992. Growth and demography of Pomacea canaliculata (Gastropoda: ampullariidae) under laboratory conditions. Malacol Rev. 25:1-12.

Estebenet AL, Martín PR. 2002. Pomacea canaliculata (Gastropoda: ampullariidae): Life-history Traits and their Plasticity. Biocell. 26:83-89.

Fang L, Wong PK, Lin L, Lan C, Qiu JW. 2010. Impact of invasive apple snails in Hong Kong on wetland macrophytes, nutrients, phytoplankton and filamentous algae. Freshwater Biol. 55:1191-1204.

Feijoó C, Rigacci L, Doyle S. 2005. Ecological regionalization of pampean streams in Argentina. Verh Internat Verein Limnol. 29:748-753.

Feijoó CS, Lombardo RJ. 2007. Baseline water quality and macrophyte assemblages in Pampean streams: a regional approach. Water Res. 41:1399-1410.

Ferreira AC. 2015. Respuestas poblacionales de macroinvertebrados a distintas calidades de agua en cuerpos lóticos de la llanura pampeana [PhD Thesis]. [La Plata]: National University of La Plata (UNLP)

Giraud-Billoud M, Vega IA, Wuilloud RG, Clément ME, Castro-Vazquez A. 2013. Imposex and novel mechanisms of reproductive failure induced by tributyltin (TBT) in the freshwater snail Pomacea canaliculata. Environ Toxicol Chem/SETAC. 32:2365-2371.

Glass N, Darby P. 2009. The effect of calcium and $\mathrm{pH}$ on Florida apple snail, Pomacea paludosa (Gastropoda: ampullariidae), shell growth and crush weight. Aquat Ecol. 43:1085-1093.

Gómez N, Licursi M. 2001. The Pampean Diatom Index (IDP) for assessment of rivers and streams in Argentina. Aquatic Ecol. 35:173-181.

Graça M, Rodrígues-Capítulo A, Ocón C, Gómez N. 2002. In situ tests for water quality assessment: a case study in Pampean rivers. Water Res. 36: 4033-4040. Retrieved from: http://www.ncbi.nlm.nih.gov/pubmed/12405412

Hayes KA, Burks RL, Castro Vazquez A, Darby PC, Heras H, Martín PR8, Qiu J-W, et al. 2015. Insights from an integrated view of the biology of apple snails (Caenogastropoda : ampullariidae). Malacologia. 58(12):245-302.

Hayes KA, Joshi RC, Thiengo SC, Cowie RH. 2008. Out of South America: multiple origins of non-native apple snails in Asia. Divers Distrib. 14:701-712. 
Hoang TC, Rand GM. 2009. Exposure routes of copper : short term effects on survival, weight, and uptake in Florida apple snails (Pomacea paludosa). Chemosphere. 76:407-414.

Hoang TC, Rogevich EC, Rand GM, Gardinali PR, Frakes R, Bargar T. 2008. Copper desorption in flooded agricultural soils and toxicity to the Florida apple snail (Pomacea paludosa): implications in Everglades restoration. Environ Pollut. 154:338-347.

Horgan FG, Felix MI, Portalanza DE, Sánchez L, Moya Rios WM, Farah SE, Espin EB. 2014. Responses by farmers to the apple snail invasion of Ecuador's rice fields and attitudes toward predatory snail kites. Crop Prot. 62:135-143.

Hurtado MA, Giménez JE, Cabral MG. 2006. Análisis ambiental del partido de La Plata. Aportes del ordenamiento territorial. $1^{\text {a }}$ ed. Buenos Aires: Consejo Federal de Inversiones.

Jackson D, Jackson D. 2009. Record of Pomacea canaliculata (Lamarck, 1822) (Ampullariidae), exotic mollusk for to North Chile. Gayana. 73:40-44.

Joshi R. 2007. Problems with the management of the golden apple snail Pomacea canaliculata: an important exotic pest of rice in Asia. In: Vreysen MJB, Robinson AS, Hendrichs J, editors. Area-wide control of insect pests. Netherlands: Springer. p. 257-264.

López Soriano J, Quiñonero Salgado S, Tarruela A. 2009. Presencia masiva de Pomacea canaliculata (Lamarck, 1822) (Gastropoda : ampullariidae) en el Delta del Ebro (Cataluña, España). Spira. 3:117-121.

Martin PR, Estebenet AL. 2002. Interpopulation variation in life-history traits of Pomacea canaliculata (Gastropoda: ampulariidae) in Southwestern Buenos Aires Province, Argentina. Malacologia. 44:153-163.

Martin PR, Estebenet AL, Cazzaniga NJ. 2001. Factors affecting the distribution of Pomacea canaliculata (Gastropoda: ampullariidae) along its southernmost natural limit. Malacologia. 43:13-23.

Melo LE, Coler RA, Watanabe T, Batalla JF. 2000. Developing the gastropod Pomacea lineata (Spix, 1827) as a toxicity test organism. Hydrobiol. 429:73-78.

Morrison WE, Hay ME. 2011. Feeding and growth of native, invasive and non-invasive alien apple snails (Ampullariidae) in the United States: invasives eat more and grow more. Biol Invasions. 13:945-955.

Mugni H. 2008. Concentración de nutrientes y toxicidad de pesticidas en aguas superficiales de cuencas rurales $[\mathrm{PhD}$ Thesis]. [La Plata]: National University of La Plata (UNLP).

Paracampo A. 2012. Relación entre la estructura de las comunidades ícticas y la calidad del agua en arroyos de cuencas con diferentes usos del suelo [PhD Thesis]. [La Plata]: National University of La Plata (UNLP).

Paruelo JM, Guerschman JP, Verón SR. 2005. Expansión agrícola y cambios en el uso del suelo. Ciencia Hoy. 15:14-23.

Peña SC, Pocsidio GN. 2007. Influence of copper on the feeding rate, growth and reproduction of the golden apple snail, Pomacea canaliculata Lamarck. Bull Environ Contam Toxicol. 79:606-608.

Pounds N, Maclean S, Webley M, Pascoe D, Hutchinson T. 2008. Acute and chronic effects of ibuprofen in the mollusc Planorbis carinatus (Gastropoda: planorbidae). Ecotox Environ Safe. 70:47-52.

Qiu JW, Chan MT, Kwong KL, Sun J. 2011. Consumption, survival and growth in the invasive freshwater snail Pomacea canaliculata: does food freshness matter? J Mollus Stud. 77:189-195.

Quirós R, Boveri MB, Petracchi CA, Rennella AM, Rosso JJ, Sosnovsky A, von Bernard HT. 2006. Los efectos de la agriculturización del humedal pampeano sobre la eutrofización de sus lagunas. In: Tundisi JG, MatsumuraTundisi T, Sidagis Galli C, editors. Eutrofização na América do Sul: causas, conseqüências e tecnologias de gerenciamento e controle. São Carlos: Instituto Internacional de Ecologia. p. 1-16.

Rawlings T, Hayes K, Cowie RH, Collins TM. 2007. The identity, distribution, and impacts of non-native apple snails in the continental United States. BMC Evol Biol 7:97.

Rodrigues Capítulo A, Tangorra M, Ocón C. 2001. Use of benthic macroinvertebrates to assess the biological status of Pampean streams in Argentina. Aquat Ecol. 35:109-119.

Seuffert ME, Martín PR. 2013a. Distribution of the apple snail Pomacea canaliculata in Pampean streams (Argentina) at different spatial scales. Limnologica. 43:91-99.

Seuffert ME, Martín PR. 2013b. Juvenile growth and survival of the apple snail Pomacea canaliculata. (Caenogastropoda: ampullariidae) reared at different constant temperatures. London: SpringerPlus. doi.10.1186/ 2193-1801-2-312.

Sierra MV. 2008. Microbentos de sistemas lóticos pampeanos y su relación con la calidad del agua: respuestas estructurales y funcionales [PhD Thesis]. [La Plata]: National University of La Plata (UNLP).

Stuart AM, Nogues Palenzuela A, Bernal CC, Ramal AF, Horgan FG. 2014. Effects of fertiliser applications on survival and recruitment of the apple snail, Pomacea canaliculata (Lamarck). Crop Prot. 64:78-87.

Tanaka K, Watanabe T, Higuchi H, Miyamoto K, Yusa Y, Kiyonaga T. 1999. Density-dependent growth and reproduction of the apple snail, Pomacea canaliculata : a density manipulation experiment in a paddy field. Res Popul Ecol. 41:253-262.

Tietze E, de Francesco CG. 2010. Environmental significance of freshwater mollusks in the Southern Pampas, Argentina: to what detail can local environments be inferred from mollusk composition? Hydrobiol. 641:133143.

Viglizzo EF, Carreño LV, Pereyra H, Ricard F, Clatt J, Pincén D. 2006. Chapter 1. Dinámica de la frontera agropecuaria y cambio tecnológico. In: Viglizzo EF, Jobbágy E, editors. Expansión de la Frontera Agropecuaria en Argentina y su Impacto EcológicoAmbiental Agropecuaria en Argentina y su Impacto Ecológico-Ambiental. Buenos Aires: Ediciones INTA. p. 8-16.

Walsh CJ, Roy AH, Feminella JW, Cottingham PD, Groffman PM, Morgan II RP. 2005. The urban stream syndrome : current knowledge and the search for a cure. J North Am Benthological Soc. 24:706-723. 